\title{
Size of Regional Trade Agreements and Regional Trade Bias
}

\author{
Michele Fratianni* and Chang Hoon Oh** \\ *Indiana University and Università Politecnica delle Marche \\ **Indiana University
}

\begin{abstract}
$\underline{\text { Abstract }}$
We test the relationship between size of regional trade agreement (RTA) and regional trade bias using a gravity equation on a large sample of 143 countries for the period 1980-2003. We find that regional trade bias declines with the size of the club and that three of the four expanding RTAs have already surpassed their 'optimal' sizes. There is no evidence that RTAs have set protection levels against outsiders noncooperatively.
\end{abstract}

Key Words: RTA, regional trade bias, trade flows

JEL Classifications: F13

*Corresponding author. E-mail: fratiann@indiana.edu. 


\section{Introduction}

RTAs have been a prominent feature of the world economy since the creation of the European Economic Community in the late 1950s. Two aspects of this feature are worth noting. The first is the rapid growth and complexity of these arrangements, although quite a few of them are bilateral agreements of small consequence for international trade (Pomfret, 2006, p.42). The second is that several plurilateral RTAs --in Europe, North America, Central America, and South East Asia-- have expanded in size and economic importance. The RTA phenomenon has sparked a growing literature on the role of RTAs in the international trade system (Panagariya, 2000). Our paper intends to address empirically that part of the literature dealing with the relationship between RTA size and regional trade bias and the potential that it may have on trade diversion against outsiders. Our research strategy is to estimate the effects of regional trade bias and external protectionism on bilateral trade flows using the gravity equation (1):

$\ln \left(\mathrm{x}_{\mathrm{ijt}}\right)=\alpha_{0}+\alpha_{1} \ln \left(\mathrm{y}_{\mathrm{i}} \mathrm{y}_{\mathrm{j}}\right)_{\mathrm{t}}+\alpha_{2} \ln \left(\mathrm{I}_{\mathrm{i}} \mathrm{I}_{\mathrm{j}}\right)_{\mathrm{t}}+\alpha_{3} \ln \left(\mathrm{d}_{\mathrm{ij}}\right)+\alpha_{4} \mathrm{FEAT}_{\mathrm{ijt}}+\beta_{1} \mathrm{RTA}_{\mathrm{ijt}}+\beta_{2} \operatorname{InterRTA}_{\mathrm{ijt}}+\mathrm{u}_{\mathrm{ijt}}(1)$,

where $\mathrm{x}_{\mathrm{ijt}}=$ the real bilateral trade between country $\mathrm{i}$ and country $\mathrm{j}$ at time $\mathrm{t}, \mathrm{y}=$ real gross domestic product, $\mathrm{I}=$ real per capita income, $\mathrm{d}=$ distance, $\mathrm{FEAT}=\mathrm{a}$ vector of dummy variables that capture idiosyncratic country characteristics, RTA= dummy variables to indicate if two trading partners belong to the same regional trade agreement, InterRTA= a dummy variable to indicate if two countries belong to different RTA, and $u_{\mathrm{ijt}}=$ error term. The vector of dummy variables in FEAT includes year dummy variables and time-invariant factors such as common language, common colonizer, shared land border, and common money; see Fratianni and Kang (2006). The gravity equation has been derived from different models of international trade 
(Anderson, 1979; Deardorff, 1998 among others) and used extensively empirically (see, for example, Frankel et al., 1998; Rose, 2000; Anderson and Van Wincoop, 2003).

Our data set consist of 215,500 annual real bilateral trade flows over the period 1980 to 2003 . The dataset and data description are available from the Indiana University CIBER Website (http://www.kelley.iu.edu/ciber/research.cfm). We identify eleven separate RTAs accounting for 40 percent of world trade: ASEAN (Association of South East Asian Nations), CARICOM (Caribbean Community and Common Market), EU (European Union), NAFTA (North American Free Trade Agreement), ANDEAN (Andean Community of Nations), CACM (Central American Common Market), MERCOSUR (Southern Common Market), PATCRA (Papua New Guinea-Australia Trade and Commercial Relations Agreement), ANZCERTA (the Australia-New Zealand Closer Economic Relations Trade Agreement), SPARTECA (South Pacific Region Trade and Economic Cooperation Agreement), and USIS (the United States-Israel Free Trade Agreement). The first four of the 11 RTAs have expanded since 1980 .

The literature generates different implications on the sign and size of $\beta_{1}$ and $\beta_{2}$. A trade-diverting RTA implies $\beta_{1}>0$ and $\beta_{2}<0$. As RTAs expand, assuming that external tariffs are set non-cooperatively, some of the trade occurring between blocs is diverted to trade inside the blocs (Krugman, 1991); this implies that $\beta_{1}$ becomes more positive and $\beta_{2}$ more negative. If external tariffs are set cooperatively, instead, both $\beta_{1}$ and $\beta_{2}$ can be positive (Krugman, 1993); and the sum of the two coefficients can be rising as a result of a generalized fall in protectionism. In other papers, the size of the RTA is determined endogenously. For example, in both Bond and Syropoulos (1996) and Andriamananjara (1999), the optimal expansion of an RTA occurs short of 
encompassing all countries in the world. In Bond and Syropoulos, the expansion is driven by the insiders' welfare level and in Andriamananjara by the insider-firms' profits. Assuming that trade can proxy for welfare or profits, these models predict an inverted $\mathrm{U}$-shaped $\beta_{1}$ in RTA size and a declining $\beta_{2}$.

\section{Findings}

OLS estimates of (1), with fixed-year effects, are reported in Table 1. Virtually all coefficients are statistically significant at the 1 percent significance level. Real imports respond positively to real GDP (with a unit elasticity), common border, shared culture (such as language and colonial relationship), and common institutions (such as currency); and negatively to distance. These results are in line with those reported by the literature. For the rest of the paper, we concentrate on the estimates of $\beta_{1}$ and $\beta_{2}$.

$$
\text { Table } 1
$$

The first column of the table shows that positive regional trade bias is present in five of the seven non-expanding RTAs: ANZCERTA and PATCRA have a negative regional trade bias. Different patterns emerge in the four expanding RTAs. For ASEAN and CARICOM, the regional trade bias is positive but declining. The decline for ASEAN occurs when the members go from nine to ten; for CARICOM from 13 to 14 . NAFTA has a negative regional bias when the membership is restricted to Canada and the United States, but then the bias becomes positive with the addition of Mexico. For the EU, the bias starts negatively and then peaks in the positive range with ten members. Thus, in three of the four expanding RTAs, the evidence is consistent with the club being too big, as seen from the viewpoint of the incumbents. NAFTA has potential for further expansion. 
The second column of the table breaks down the regional trade between old and new members of the club; the table reports the results only for the EU. In the EU10, the regional trade bias among the old nine members, conditional on the $10^{\text {th }}$ member (Greece), translates into 13 percent more trade than not being in the club $(\exp (0.1224)=1.13)$. The entry of Greece adds 37 percent more trade $(\exp (0.3184)=1.37)$ between Greece and the old members relative to not being in the club. Since the interaction among old members represents 80 percent of the observations, while the interaction between old members and Greece account for 20 percent of the observations, we obtain that the total regional trade bias in the EU10 is approximately 18 percent. Similar reasoning applies to EU12 and EU15. Portugal and Spain add a positive regional trade bias in their interaction with the old ten members, but this bias is compensated by an opposite bias of the old members interacting among themselves and of Portugal interacting with Spain. Austria, Finland, and Sweden also add a positive regional trade bias in their interaction with the old 12 members and with one another, but this bias is compensated by the negative bias of the old 12 members interacting among themselves. In sum, as the club expands old members lose some of the positive regional trade bias to new members. The total bias depends on these opposing forces: the size of $\beta_{1}$ peaks at EU10.

The migration of positive regional trade bias from old to new members holds also for ASEAN and CARICOM; the estimation is not shown but is available upon request. In ASEAN10, the regional trade bias among the old nine members, conditional on the $10^{\text {th }}$ member (Cambodia), is 241 percent and is approximately half of the bias without Cambodia. The entry of the latter into the club adds a 230 percent regional bias but its weight in the club is very small. The result is a sharp reduction in the overall trade bias of ASEAN10 with respect to ASEAN9. Similarly, in 
CARICOM14, the 13 old members, conditional on the $14^{\text {th }}$ member (Haiti), experience a sharp reduction in the regional bias relative to CARICOM 13; the marginal impact on the club's trade bias of Haiti, furthermore, is statistically not different from zero. Consequently, the total regional bias falls in CARICOM14 relative to CARICOM13.

The positive and statistically significant estimate of $\beta_{2}$ is consistent with the hypothesis that RTAs set external tariffs cooperatively. GATT, the WTO, and multilateral rounds have played a role in the global reduction of tariff rates and nontariff barriers. This result is not consistent with the view that RTAs are stumbling blocs to freer trade.

\section{Conclusions}

We have tested the relationship between RTA size and regional trade bias using a gravity equation on a large sample of 143 countries for the period 1980-2003. The critical result is that regional trade bias declines with the size of the club. Seen from the perspective of the incumbents, three of the four expanding RTAs have already surpassed their 'optimal' size. This could result not only from strategic trade considerations, but also from the rising cost of decision-making as the club expands. We have also evidence that RTAs have set protection levels against non-members cooperatively rather than non-cooperatively. 


\section{References}

Anderson, J.E. (1979) A theoretical foundation for the gravity equation, American Economic Review, 69, 106--115.

Anderson, J.E. and van Wincoop, E. (2003) Gravity with gravitas: a solution to the border Problem, American Economic Review, 93, 170--192.

Andriamananjara, S. (1999) On the size and number of regional integration arrangements: a political economy model, World Bank Policy Research Working Paper No.2117.

Bond, E.W. and Syropoulos, C. (1996) The size of trading blocs, market power and world welfare effects, Journal of International Economics, 40, 411--437.

Frankel, J.A., Stein, E. and Wei, S-J. (1998) Continental trading blocs: are they natural or supernatural?, in Regionalization of the World Economy (Ed.) J.A. Frankel, The University of Chicago Press, Chicago, pp.91--113.

Fratianni, M. and Kang, H. (2006) Heterogeneous distance-elasticities in trade gravity models, Economics Letters, 90(1), 68--71.

Krugman, P. (1991) Is bilateralism bad?, in International Trade and Trade Policy (Eds.) E. Helpman and A. Razin, MIT Press, Cambridge, MA, pp.9--23. , 1993, Regionalism versus multilateralism: analytical notes, in New Dimensions in Regional Integration (Eds.) J. de Melo and A. Panagariya, Cambridge U. Press, Cambridge, pp.58--78.

Panagariya, A. (2000) Preferential trade liberalization: the traditional theory and new developments, Journal of Economic Literature, 38, 287--331.

Pomfret, R. (2006) Regional trade agreements, in Regional Economic Integration (Ed.) M. Fratianni, Elsevier, Amsterdam, pp.39--54.

Rose, A.K. (2000) One money, one market: The effects of common currency on trade, Economic Policy, 30, 9--45. 
Table 1: The expansion of RTAs and International Trade, 1980-2003

\begin{tabular}{|c|c|c|}
\hline Dependent variable: real bilateral imports & $(1)$ & $(2)$ \\
\hline Intercept & -27.9238 & -27.9272 \\
\hline Log of real expenditure & 0.8941 & 0.8943 \\
\hline Log of real per capita exp. & 0.1211 & 0.1210 \\
\hline Log of distance & -1.0449 & -1.0453 \\
\hline Common border & 0.4608 & 0.4637 \\
\hline Common language & 0.3404 & 0.3404 \\
\hline Common colonizer & 0.7457 & 0.7456 \\
\hline Colonial relationship & 1.4067 & 1.4067 \\
\hline Common currency & 0.5004 & 0.5025 \\
\hline InterRTA & 0.2425 & 0.2425 \\
\hline ANDEAN & 0.9007 & 0.8987 \\
\hline ANZCERTA & -1.4888 & -1.4895 \\
\hline $\mathrm{CACM}$ & 1.9923 & 1.9902 \\
\hline MERCOSUR & 0.9500 & 0.9469 \\
\hline PATCRA & -1.5986 & -1.5991 \\
\hline SPARTECA & 3.8335 & 3.8338 \\
\hline USIS & 1.3274 & 1.3268 \\
\hline ASEAN6(1968-1995) & 2.1635 & 2.1623 \\
\hline ASEAN7(1996-1997) & 2.2888 & 2.2875 \\
\hline ASEAN9(1998) & 2.0187 & 2.0175 \\
\hline ASEAN10(1999-2003) & 1.2252 & 1.2242 \\
\hline CARICOM11(1974-1983) & 3.2958 & 3.2964 \\
\hline CARICOM12(1984-1995) & 2.5867 & 2.5872 \\
\hline CARICOM13(1996-1998) & 3.3517 & 3.3521 \\
\hline CARICOM14(1999-2003) & 1.8371 & 1.8373 \\
\hline NAFTA2(1989-1993) & -0.4288 & 0.4245 \\
\hline NAFTA3(1994-2003) & 0.7676 & 0.7643 \\
\hline EU9(1973-1980) & -0.2119 & -0.2138 \\
\hline EU10(1981-1985) & 0.1730 & \\
\hline EU12(1986-1994) & $0.0219^{* *}$ & \\
\hline EU15(1995-2003) & -0.0012 & \\
\hline EU10: within EU9(1981-1985) & & 0.1224 \\
\hline EU10: EU9 \& Greece(1981-1985) & & 0.3184 \\
\hline EU12: within EU10(1986-1994) & & $-0.0482^{*}$ \\
\hline EU12: EU10 \& [Portugal, Spain](1986-1994) & & 0.1616 \\
\hline EU12: within Portugal and Spain(1986-1994) & & -0.3191 \\
\hline EU15: Within EU12(1995-2003) & & -0.1122 \\
\hline EU15: EU12 \& [Austria, Sweden, Finland](1995-2003) & & 0.1384 \\
\hline EU15: within Austria, Sweden, Finland(1995-2003) & & 0.2774 \\
\hline Obs. & 215,500 & 215,500 \\
\hline $\mathrm{R}^{2}$ & 0.6139 & 0.6139 \\
\hline
\end{tabular}

Notes: Years of expansion of the RTAs are obtained from the websites of the RTAs and of the WTO. "EU10: within EU9" refers to bilateral flows among the old nine EU members; "EU10: EU9 \& Greece" refers to bilateral flows between each of the nine old members and Greece. Similar reasoning applies to further expansions of the EU. All coefficients are significant at the $1 \%$ level, unless noted otherwise. ${ }^{*}$ indicates that the coefficient is significant at $10 \%$ level; ${ }^{* *}$ indicates that the coefficient is not significant at 10\% level. All models include fixed-year effects, which are not reported. 